\title{
Teacher's Expressive Speech Act in Indonesian Learning Process at SMPN 2 Lareh Sago Halaban
}

\author{
Wilona Ayunda Putri ${ }^{1, *}$ Ermanto $^{1}$ Ngusman $^{1}$
}

\author{
${ }^{I}$ Indonesian Department, FBS Universitas Negeri Padang, Padang, Sumatra Barat 25131, Indonesia \\ *Corresponding author. Email: Wilonaayundaputri@gmail.com
}

\begin{abstract}
Speech acts is a very important part of communication. The purpose of this study was to explain the types, functions of expressive speech act strategies used by the Indonesian language teachers in learning process in the SMP Negeri 2 Lareh Sago Halaban. This research is a qualitative descriptive research. Data were collected using the technique of observing, and recording. Data were analyzed by the process of: (1) selecting data, (2) transcribing the recorded data, (3) classifying the data based on the type, function and strategy of expressive speech acts, (4) connecting research findings with the background, (5) drawing conclusions. The results of this study are the type of non-expressive speech that teachers tend to use is the type of praise. Types of expressive speech acts that are rarely used are expressive speech acts of complaining, criticizing, blaming, apologizing, saying congratulations, saying thank you. Expressive speech acts of praising, saying thank you, saying goodbye are used for fun functions. Expressive speech acts are of criticizing, blaming, complaining are used for contradictory functions.
\end{abstract}

Keywords: Speech acts, Expressive, Learning

\section{INTRODUCTION}

Expressive speech acts are one of the five "basic" categories of speech acts according to Searle [1] that is less studied [2]. The causes of these expressive speech acts are not well studied because there are many meanings from the level of confusing expression in this speech act [3]. Although there are certain categories of the expressive speech act on the basic of speech has not been done. Especially saying thanks and praise have receives wider attention. The overall classification of the expressive speed speech acts on the basic speech acts has not been done yet. Among Searle's on five basic categories of speech acts, namely representative, directive, commission, declaration and expression, the first three have received great attention while the latter two are less well researched on expressive speech acts is still less well studied [2].

Research on expressive speech acts is still rarely studied [4]. Guiraud et al conducted research on "the logical formalization of expressive speech acts". In analyzing expressive speech acts, there are certain emotions to express speech. Norrick [5] has divided expressive illocutionary actions according to emotional levels. In Norrick's research, there are three conditions in expressive illocutionary action, namely conditions of factive judgments, value judgments, and roles.

Guiraud [4] has used an approach based on emotional theory and formal logic to organize expressive speech acts from the point of view of underlying psychological attitudes with their main bases of joy, sadness, approval, and disapproval. However, the formal approach to expressive speech acts seems to have not been applied and tested in the speech act. Based on the relevant previous research descriptions, research on expressive speech acts has been conducted.

Teachers as good teachers and educators must be able to arouse students' passion for learning and include the cultivation of character in their subjects [6]. In fact, not all education in Indonesia has actually implemented character education. One example, he still finds a teacher who puts forward his emotions during learning is not instilling his character values. The inculcation of character education values from a teacher can be seen from the various forms of speech delivered by the teacher.

Yule [7] categorizes speech acts into five types. The five types of speech acts are declaration, representative, expressive, directive and commissive. Speech act in learning interactions is one of the language studies that is interesting to study because this is not only related to linguistic aspects but also socio-cultural aspects. This research is motivated by the lack of harmonious communication between teachers and students in the school environment. In addition, the teacher's lack of expressive speech in responding to student responses to something has been done well. Another reason is the lack of expressive speech or a reciprocal relationship between students and teachers and other students in learning interactions. This is due to the lack of student activity in communicating. The teacher's speech acts in the field also do not fully reflect humanist speech in learning interactions [8].

The teacher realizes that mathematics is a relatively difficult subject for students so it requires patience and 
diligence to convey the material. Of the several types of illocutionary speech acts that exist, the non-speech used by the teacher when teaching in the classroom is quite diverse. When viewed from the frequency level of the number of interactions between teachers and students in the learning process, the speech acts. That can be in the form of expressions of thoughts and feelings, such as: praise, thanks, condolences, criticism, and so on. Yasin [9] also divides context into two, namely, extra-linguistic or situational contexts and linguistic contexts.

The expressive speech acts used by the teacher in interactions with students in the classroom are closely related to motivation, both intrinsic motivation and extrinsic motivation. Direct motivation will build a more conducive learning atmosphere for students to be more enthusiastic in learning the material provided by the teacher. Rustono [10] also defines context as a means of clarifying an intention. The means are divided into two types, namely (1) part of the expression which can support the clarity of an intention (co-text); (2) in the form of situations related to an event (context). In addition, Rustono [10] also defines speech situations as situations that give birth to speech. Rustono's opinion can be seen that speech is the result and speech situation is the cause. In communication there is no speech without a speech situation. One of the them used by the teachers Indonesia language learning process at SMP Negeri 2 Lareh Sago Halaban is expressive speech. Speech spoken complaining, praising, saying thank you, congratulating, criticizing, blaming, and apologizing.

In the greeting speech in the context of the teacher entering the classroom when starting learning. The teacher greets the students in a standing position in front of the class and looks at the students with cheerful facial expressions, looks fresh, and in an excited voice.

The research objective was to explain expressive speech acts. Illocutionary speech acts are speech acts which in addition to function to say something and can also be used to do something Andreanus [11]. This illocutionary speech act is known as The Act of Doing Something [12]. This speech act is a speech act whose purpose of delivery depends on who, when, and where the speech is performed, so that this speech is not as easily identified as a local speech act.

\section{METHOD}

This research is a qualitative research with descriptive method. Qualitative research seeks to see, observe, and appreciate the problem to be studied as a complex phenomenon that must be viewed holistically or thoroughly. According to Saukah [13], qualitative research seeks to reveal symptoms thoroughly and according to the holostic-contextual context through collecting data from natural settings by utilizing self-research as a key instrument.

This research is at SMP Negeri 2 Lareh Sago Halaban because the teachers are diverse and active in speaking in teaching.
Research informants were determined through several criteria, namely: 5 years minimum teaching experience. (2) the background of the teacher is in accordance with the subject being taught, (3) using Indonesian in teaching, not the regional language (4) tends to use the lecture and discussion method in learning.

In qualitative research, the researcher is the main instrument, because the researcher determines the source of the data and records speech acts in class. The complementary instrument for data collection is the data identification format. First, the type of data identification format and expressive speech acts. Second, the format for identifying the function of expressive speech acts in Indonesian language learning and third, the format for identifying speech strategies. This study uses a series of data collection activities that can be carried out by several techniques, namely (1) see the SBLC competency free fold), 2) take notes and (3) record techniques [14].

\section{RESULT AND DISCUSSION}

The types of expressive speech acts of teachers of Indonesian Language learning process at SMP Lareh Sago Halaban found in the research data can be grouped into six types. The types of expressive speech acts are 1 . Complaining, 2. Praising, 3. Criticizing, 4. Blaming, 5. Apologizing, 6. Congratulating, 7. Saying thank you. The following describes each type of speech act.

\section{Complain}

The type of complaining expressive speech act uttered by the teachers Indonesian language learning process at SMP Negeri 2 Lareh Sago Halaban."Found as many as 1 speech. This type of complaining expressive speech act can be seen in the following example.

Teacher: Mother is tired of explaining the lesson in front, but you guys make fuss

Students: (they are busy telling stories)

Context: The teacher is explaining the lesson (Indonesian teacher: VIII).

In the example above, expressive speech of the type of complaining in the speech of 25 tired words is spoken by the teacher to show the teacher's complaint to students for their actions in the learning process.

\section{Praise}

The types of complaining expressive speech act uttered by the teachers of Indonesian learning process at SMP Negeri 2 Lareh Sago Halaban. Found as many as 60 speeches. This type of praising expressive speech act can be seen in the following example.

Teacher: who knows the meaning of a persuasive text?

Student: the persuasive text of a paragraph whose contents are in the form of invitations or persuading the reader to do or follow what the writer says in the paragraph.

Teacher: right

Context: The teacher is explaining the lesson (Indonesian teacher: VIII) 
In the example above, the expressive speech of the type of praise in the 4-word speech was really spoken by the teacher to show appreciation to students for the answers given. The answers given by students are considered to be exactly what the teacher expects about the meaning of persuasive text.

Another type of expressive speech act of praise can be seen in the following example.

Teacher: what is the purpose of the persuasion text?

Students: so that readers believe that the idea, idea, or opinion is true and proven and also carry out what is the invitation of the idea.

Teacher: right

Context: The teacher is explaining the lesson (Indonesian teacher: VIII).

In the example above, expressive speech, the type of praise in the correct 5-word speech was spoken by the teacher to show appreciation to students for the answers given. The answers given by students are considered correct as expected by the teacher regarding the meaning of the purpose of the persuasion text.

The types of expressive speech acts of praise can also be seen in the following examples.

Teacher: Does anyone know the characteristics of a persuasion text?

Students: a. its main purpose is to influence readers.

b. Trying to convince readers to do or believe what the author wrote.

Persuasion paragraphs usually avoid conflict so that the reader's trust is not lost and so that an agreement of opinion between the writer and the reader is reached.

Teacher: Good

Context: The teacher is explaining the lesson (Indonesian teacher: VIII).

In the example above, expressive speech of the type of praise in the 6 good words spoken by the teacher to show appreciation to students for the answers given. The answers given by students are considered to be exactly what the teacher expects about the characteristics of the persuasion text.

The types of expressive speech acts used by the teacher in the Indonesian language learning process at SMP N2 Lareh Sago Halaban totaled 87 utterances. The expressive type of praise spoken by the teacher is related to providing reinforcement in the form of appreciation and motivation for what has been done by students. To appreciate the students' actions, the teacher praises the students with verbal language, namely using the modality, such as, good, correct, correct, yes, (with reaffirmation of the spoken speech), steady, precise and uses symbols with a thumbs up and applause. The teacher uses expressive speech of praise to express feelings of pleasure and pride in the actions of the students. This action is in the form of a student's speech when the teacher asks questions and is in the process of discussion in class.

Praise expressive speech act is used for fun function. Expressive speech acts praise the teacher, because the teacher still tries to build intimacy with the students as his speech partners. In the context of the speech, the teacher considers the knowledge they have to be higher than students' knowledge. However, the teacher still appreciates the students' efforts, namely by providing statements that make students more valued for their opinions. In addition, this award is also given by the teacher in the form of a value prize if the answer is correct.

For praising expressive speech, the effect felt by students as speech partners is joy and pride. Students feel happy and proud because students feel appreciated for what they have done, such as answering teacher questions. This is in accordance with what the students said in the interview.

\section{Gratitude}

The type of non-expressive speech of the teachers Indonesia language learning process by student in SMP Negeri 2 Lareh Sago Halaban which is classified as nonexpressive speech saying thank you was found in 2 utterances. The type of non-speech expressive speech act of saying thank you can be seen from one of the following examples.

Teacher: Please get the worksheets at your mother's table! Student: This is thump

Teacher: Thank you

Context: The teacher is explaining the lesson (Indonesian teacher: VIII).

In the example above, expressive speech types say thank you to 2-word speech thank you which was spoken by the teacher. The teacher said that the type of thank you said when the student worksheets were taken by the students.

Expressive speech said thank you was spoken by the teacher as a form of expression of the teacher's gratitude to the students because the students had done what the teacher wanted and for the enthusiasm of the students who had followed the lesson well. The teacher thanks him because the students have done what the teacher wants, in which the teacher's speech uses imperative speech to students. From the actions taken by students on these imperative speeches, the teacher published expressive speech saying thank you as an expression of his pleasure.

\section{Congratulating}

The type of non-expressive speech Indonesian language teachers learning process by student in SMP Negeri 2 Lareh Sago Halaban which were classified as expressive speech acts to congratulate were found as many as 2 utterances.

This type of congratulatory expressive speech act can be found in one of the following examples.

Teacher: Good morning everyone.

Student: Morning thump.

Context: before the teacher starts learning (Indonesian teacher: VIII).

In the example above, the expressive type of speech congratulates the 1 word good morning spoken by the teacher. Type of congratulation is spoken by the teacher when the teacher first enters the room.

Teacher IX also said congratulatory speech acts in the Indonesian language learning process. In the following example. 
Teacher: good afternoon everyone

Student: Morning thump

Context: Before the teacher starts learning (Indonesian teacher: IX).

In the example above, the expressive type of speech congratulates the 54 words good afternoon spoken by the teacher. The type of saying good morning is spoken by the teacher when the teacher first enters the room.

In the context of the research carried out, the expressive utterances of the type of congratulation consisted of 3 utterances which were spoken by the teacher regarding the context of the time the teacher started the lesson, namely in the morning. The teacher tells an expressive speech congratulating him for making the learning atmosphere in the morning lived with enthusiasm. Expressive speech acts to congratulate in the context of learning are used by the teacher for a fun function with a strategy of speaking frankly without further ado.

\section{Criticizing}

This type of expressive speech act is critical of what was spoken by the Indonesian languange teachers learning process at SMP Negeri 2 Lareh Sago Halaban. Found as many as 1 speech.

This type of critical expressive speech act can be seen in the following example.

Teacher: don't sit like that, it will become a habit later.

Student: Sorry

Context: The teacher is explaining the lesson (Indonesian teacher: IX).

In the example above, expressive speech criticizes the 68 words don't sit like that which was spoken by the teacher to show criticism of students' behavior in the learning process.

\section{Blaming}

The type of expressive speech acts blamed by the teacher in the Indonesian language learning process at SMP Negeri 2 Lareh Sago Halaban. Found as many as 2 utterances.

This type of blaming expressive speech act can be seen in the following example.

Teacher: please do lks pages 26 to 27

Student: OK

Teacher: time is up, please collect lks. Don't blame my mother, the value isn't there if someone doesn't collect LKS, because it's your fault.

Context: The teacher is explaining the lesson (Indonesian teacher: VIII).

In the example above, the expressive speech criticizes your 41 wrong words uttered by the teacher to show the teacher blames the student if the score is not there if you do not submit the assignment.

Types of blaming expressive speech acts can be seen in the following example.

Teacher: no one is wearing a jacket in the learning process, please open it.

Student: Yes
Context: The teacher is explaining the lesson (Indonesian teacher: IX).

In the example above, expressive speech criticizes the 67 words, none of which is spoken by the teacher to show that the teacher blames students who wear jackets in the learning process.

\section{Apologizing}

The type of expressive speech act of apologizing was spoken by the Indonesian Language Teachers learning process at SMP Negeri 2 Lareh Sago Halaban. Found as many as 1 speech.

Teacher: I'm sorry I couldn't invite you to your son's wedding.

Student: It's okay

Context: Before the teacher starts learning (Indonesian teacher: IX).

In the example above, the expressive speech apologizes to the 2 apologies spoken by the teacher to show the teacher apologizes for not inviting students to their child's wedding

\section{CONCLUSION}

The type of non-expressive speech that teachers tend to use is the type of praise. Types of expressive speech acts that are rarely used are expressive speech acts of complaining, criticizing, blaming, apologizing, saying congratulations, saying thank you. This research is expected that students can continue to develop their potential in using language in communicating and interacting at school. The ability of students to use good and polite language in communicating shows good student character as well.

\section{REFERENCES}

[1] Searle. (1969). Speech Acts An Essay in The Philosophy of Language. Oxford: Basil Blacwell

[2] Ronan, P. (2015). Categorizing expressive speech acts in the pragmatically annotated SPICE Ireland corpus. ICAME Journal, 29, 25-45.

[3] Yuyun, Y \& Lalu B. S. (2017). An analysis of expressive speech acts used by steve rogers as the main character in civil war movie. Journal of English Language and Language Teaching (JELLT). 1 (2), $61-67$

[4] Guiraud, Nadine, Donimique Longin, Emiliano Lorini, Sylvie Pesty and Jérémy Rivière. (2011). The face of emotions: A logical formalization of expressive speech acts. In K. Tumer, P. Yolum, L. Sonenberg and P. Stone (eds.). Proceedings of the 10th International Conference on Autonomous Agents and Multiagent Systems (AAMAS 2011), May, 2-6, 2011, Taipei, 
Taiwan, 1031- 1038. Richland, SC: International Foundation for Autonomous Agents and Multiagent Systems.

[5] Norrick, Neal R. (1978). Expressive illocutionary acts. Journal of Pragmatics 2 (3): 277-291.

[4] Ronan, P. (2015). Categorizing expressive speech acts in the pragmatically annotated SPICE Ireland corpus. ICAME Journal, 29, 25-45.

[6] Wardani, Indri Kusuma \& Agus Setiawan. (2014). Tindak tutur ekspresif guru sebagai wujud kesantunan positif dalam penanaman nilai pendidikan karakter di sekolah. Prosiding Seminar Nasional PRASASTI.

[7] Yule (2006: 92 -94) yang mengkategorikan tindak tutur menjadi lima jenis. Kelima jenis tindak tutur tersebut adalah dekslarasi, repsesentatif, ekspresif, direktif dan komisif.

[8] Zulaeha, I. \& Lita, D.A. (2013). Tindak tutur ekspresif humanis dalam interaksi pembelajaran di SMA Negeri 1 Batang: analisis wacana kelas. Seloka 6 (2) 2017.

[9] Yasin, Anas. (2008). Tindak Tutur Sebuah Novel Gramatikal Komunikatif. Padang: Sukabina Offset.

[10] Andreanus, Jansen. (2015). Tindak ujar ekspresif dalam film Freedom Writer karya Erin Gruwell suatu kajian pragmatik. Jurnal Humaniora Universitas Sam Ratulangi 1-14.

[11] Rustono. (1999). Pokok-pokok pragmatik. Semarang: IKIP Semarang.

[12] Wijana, I Dewa Putu. dan Muhammad Rohmadi (2009). Analisis Wacana Pragmatik: Kajian Teori dan Analisis. Surakarta: Yuma Pustaka

[13] Saukah, Ali, et al. 2007. Pedoman Penulisan Karya Ilmiah. Malang: UM.

[14] Sari, Fenda Dina P. (2012). Tindak tutur dan fungsi tuturan ekspresif dalam acara Galau Nite di Metro TV: Suatu kajian pragmatik. Jurnal Skriptorium $1(2)$.

[15] Moleong, Lexy. J. (2014). Metode penelitian kualitatif. Bandung: Remaja Rosdakarya.. 